Ireneusz MILEWSKI*

\title{
PIENIĄDZ W HISTORIA LAUSIACA AUTORSTWA PALLADIUSZA Z HELENOPOLIS ${ }^{* *}$
}

Problematyka gospodarcza oraz związane z nią kwestie pieniężne nie są nazbyt często eksponowane w późnoantycznej literaturze patrystycznej. Dla uważnego czytelnika stanowi ona jednak olbrzymią skarbnicę informacji. Nie jest to co prawda łatwy materiał do interpretacji, wiele w nim toposów oraz figur retorycznych, które badacza niewprawionego w arkana tego typu źródeł moga sprowadzić na manowce poznania historycznego. Dla zgłębienia badanej problematyki każde źródło ma jednak wymierną wartość, nawet jeśli przekazane w nim informacje nie są nazbyt precyzyjne. Potwierdzeniem zasadności tak brzmiącego stwierdzenia jest wskazanie na walory późnoantycznej literatury hagiograficznej. Obrazując życie i cuda czynione za wstawiennictwem świętego męża, autorzy tych tekstów na marginesie swych relacji podaja, najczęściej w sposób niezamierzony, wiele cennych informacji obrazujących realia epoki w której żył ich bohater (jeśli ta powstała na krótko po jego śmierci) albo też jej autor ( $\mathrm{z}$ reguły przesunięcie w czasie sięga co najwyżej kilkudziesięciu lat, stąd też uchwycone w relacji realia z reguły uznać można za tożsame). Nierzadko są to również informacje dotyczące stosunków społeczno-gospodarczych w cesarstwie późnorzymskim. Poniższe krótkie studium jest próbą wyłuskania informacji dotyczących pieniądza tylko z jednego z tych tekstów, a mianowicie z Historia Lausiaca autorstwa Palladiusza z Helenopolis.

Zanim przejdziemy do omawiania interesującej nas problematyki, kilka słów należałoby poświęcić autorowi interesujących nas tu relacji. Niewiele wiadomo o Palladiuszu. Większość informacji na temat biskupa bityńskiego Helenopolis odnajdujemy w jego własnych pismach. Palladiusz, uczeń Ewagriusza z Pontu, najprawdopodobniej urodził się w 363/364 r. w Galacji, nie wykluczone, że w Asponie ${ }^{1}$. Przesłanką uprawdopodabniającą tak brzmiące stwierdzenie może być fakt, iż w mieście tym Palladiusz objął w 417 r. tron

* Dr hab. Ireneusz Milewski, prof. UG - profesor nadzwyczajny w Zakładzie Historii Starożytnej w Instytucie Historii na Wydziale Historycznym Uniwersytetu Gdańskiego; e-mail: hisim@ univ. gda.pl.

** Artykuł powstał $\mathrm{w}$ ramach prac nad projektem finansowanym przez Narodowe Centrum Nauki (UMO-2015/17/B/HS3/00135).

${ }^{1}$ Por. A. Hübner, Einführung, w: Palladius, Historia Lausiaca. Geschichte aus dem frühen Mönchtum, Übersetzt und kommentiert von A. Hübner, FCh 67, Freiburg - Basel - Wien 2016, 37 - 
biskupi. W późnej starożytności nierzadko zdarzało się tak, iż ludzie wywodzący się z miejscowych elit przejmowali lokalne trony biskupie ${ }^{2}$. W latach 386-397 Palladiusz podróżował po Palestynie i Egipcie, odwiedzając tamtejsze miejsca święta oraz mnisze skupiska, zbierając przy tym informacje, które następnie wykorzystał dla potrzeb interesującego nas tu tekstu. Najprawdopodobniej w 400 r. z inicjatywy stołecznego biskupa Jana, Palladiusz zostaje ustanowiony pasterzem bityńskiego Helenopolis ${ }^{3}$, zaś w 403, jako stronnik obalonego Chryzostoma udaje się na Zachód, na dwór cesarza Honoriusza, gdzie zabiega o interwencję w sprawie zesłanego biskupa Konstantynopola ${ }^{4}$. Po powrocie w 406 r. na Wschód, Palladiusz zostaje aresztowany, osadzony w trackiej twierdzy Athyra, a następnie wskutek odmowy odstąpienia od poparcia dla Chryzostoma zesłany do egipskiej Syene ${ }^{5}$, skąd powraca w 412 lub 413 r. (po śmierci Teofila Aleksandryjskiego). Ok. 417 r. obejmuje on tron biskupi w galacyjskiej Asponie ${ }^{6}$. Nie posiadamy żadnych informacji na temat daty jego śmierci. Fakt, iż na Soborze Efeskim I (431) biskupstwo galacyjskiej Aspony reprezentował biskup Euzebiusz, wcale nie musi oznaczać, iż Palladiusz już wówczas nie żył ${ }^{7}$.

Palladiusz pozostawił po sobie dwa dzieła. Pierwsze, napisane na wygnaniu w latach 406-413, to Dialogus de vita Joannis Chrysostomi (Dialog o życiu św. Jana Chryzostoma $)^{8}$. Drugie jego dzieło Historia Lausiaca, powstało ok. 418419 r., kiedy nasz autor sprawował już urząd biskupa galacyjskiej Aspony ${ }^{9}$. Palladiusz dedykował je kubikulariuszowi Lausosowi, wysokiemu urzędnikowi

39; Ch. Schulze, Die Wundererzählungen in Palladius'Historia Lausiaca. Eine medizinhistorische Betrachtung, ZACh 17 (2013) 88.

${ }^{2}$ Por. I. Milewski, Depozycje i zsyłki biskupów w cesarstwie wschodniorzymskim (lata 325451), Gdańsk 2008, 29-30.

${ }^{3}$ Por. D.S. Katos, Palladius of Helenopolis. The Origenist Advocate, Oxford 2011, 16; Hübner, Einführung, s. 40.

${ }^{4}$ Por. Milewski, Depozycje i zsyłki, s. 418-420.

${ }^{5}$ Tamże, s. 309, 338-339 i 361; tenże, Jan Chryzostom i jego stronnicy $w$ starciu z patriarcha aleksandryjskim Teofilem, w: Czasy Jana Chryzostoma i jego pasterska pedagogia, red. N. Widok, Opolska Biblioteka Teologiczna 105, Opole 2008, 103. Palladiusz przebywając na wygnaniu w Egipcie podtrzymywał kontakt korespondencyjny z biskupem Janem, por. Joannes Chrysostomus, Epistula 113, PG 52, 669; 118, PG 52, 673; 148, PG 52, 699.

${ }^{6}$ Por. Hübner, Einführung, s. 44.

${ }^{7}$ Por. E.D. Hunt, Palladius of Helenopolis. A Party and its Supporters in the Church of the Late Fourth Century, JTS 24 (1973) 456-457 i 471-476; K. Pollmann, Palladius von Helenopolis, LAChL 472-473; M. Starowieyski, Wstę, w: Palladiusz, Opowiadania dla Lausosa (Historia Lausiaca), ŹM 12, Kraków 1996, 15 i 23; E. Wipszycka, „Historia Lausiaca” Palladiusza, w: Chrześcijaństwo u schytku starożytności. Studia źródtoznawcze, red. T. Derda, E. Wipszycka, I, Warszawa 1997, 230-233; Katos, Palladius of Helenopolis, s. 16.

${ }^{8}$ Éd A.-M. Malingrey - P. Leclercq: Palladios, Dialogue sur la vie de Jean Chrysostome, $\mathrm{SCh}$ 341, Paris 1988.

${ }^{9}$ Por. Katos, Palladius of Helenopolis, s. 98-22. 
na dworze cesarzy Arkadiusza i Teodozjusza $\mathrm{II}^{10}$. Biskup Helenopolis zestawia w nim żywoty 71 świętych mężów oraz niewiast, poznanych w przeważającej mierze podczas wieloletniego pobytu w Palestynie oraz w Egipcie. Historia Lausiaca będąca przede wszystkim cennym źródłem dla poznania dziejów monastycyzmu egipskiego przełomu IV i V wieku ${ }^{11}$ interesuje nas jednak z innego powodu. Chcemy mianowicie przeanalizować pojawiające się w niej relacje dotyczące pieniądza. Nawiązania do tej kwestii pojawiają się w Historia Lausiaca $\mathrm{w}$ kilku kontekstach. Są to informacje na temat sum pieniężnych przekazywanych w przeważającej mierze przez późnorzymską arystokrację na rzecz Kościoła, wspólnot monastycznych, finansowania działalności dobroczynnej oraz nieliczne, a w dodatku jeszcze wątpliwe pod względem poznawczym informacje na temat ówczesnych cen i płac.

Zacznijmy od informacji dotyczących przekazywania przez późnorzymską arystokrację sum pieniężnych na rzecz Kościoła oraz wspólnot monastycznych $^{12}$. Wśród najhojniejszych arystokratek rzymskich, których działalność opisuje Palladiusz odnajdujemy Melanię Młodszą († ok. 439), jedną z najzamożniejszych arystokratek późnorzymskich. Wywodziła się ona ze starorzymskiego rodu Waleriuszy, który posiadał majątki rozproszone na terenie całego cesarstwa $^{13}$. Swego rodzaju przewodnikiem duchowym Melanii, jak określa go sam Palladiusz, był bliżej nie znany nam prezbiter Paweł, który okazał się pomocny w spieniężeniu - zaznaczmy - tylko części majątku Melanii, jaki rozsiany był na terenie zachodnich prowincji cesarstwa. W pierwszych latach V w. przetransferowano na Wschód olbrzymie sumy złota, co najmniej 45 tys. solidów, jakie Melania uzyskała ze sprzedaży części swych dóbr italskich. Srodki uzyskane ze sprzedaży części majątku na Zachodzie, zaufany Melanii, bliżej nie znany mnich Paweł z Dalmacji, dostarczył do Jerozolimy, gdzie Melania rozdzieliła je pomiędzy Kościoły Egiptu i Tebaidy (10 tys. solidów

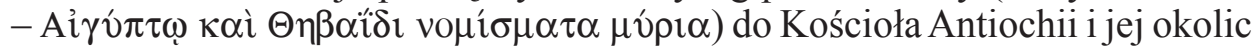

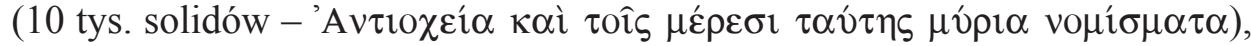

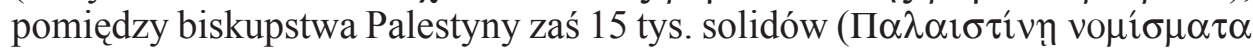
$\mu u ́ p ı \alpha \pi \varepsilon v \tau \alpha \kappa \imath \sigma \chi i ́ \lambda \imath \alpha)$. Natomiast pomiędzy bliżej nieokreślone „Kościoły na wyspach" oraz pomiędzy duchownych przebywających na wygnaniu rozdzielono kolejne 10 tys. solidów (

${ }^{10}$ Por. Lausus 1, PLRE II 660; S.Tougher, The Eunuch in Byzantine History and Society, London - New York 2008, 40; Schulze, Die Wundererzählungen in Palladius' Historia Lausiaca, s. 88; Hübner, Einführung, s. 7.

${ }^{11}$ Por. Schulze, Die Wundererzählungen in Palladius' Historia Lausiaca, s. 89; Hübner, Einführung, s. 45-50.

${ }^{12}$ Zagadnienie to omawia od strony prawnej, w kontekście tworzenia fundacji, Monika Wójcik (Fundacje dobroczynne w rzymskim prawie poklasycznym, Lublin 2003, 41-91).

${ }^{13}$ Por. F.E. Consolino, Sante o patrone? Le aristocratiche tardoantiche e il potere della carità, „Studi Storici” 30 (1989) 969-991; P. Szczur, Melania Młodsza, EK XII 488; M.R. Salzmann, The Making of a Christian Aristocracy. Social and Religious Change in the Western Roman Empire, Cambridge - London 2002, 24-26. 


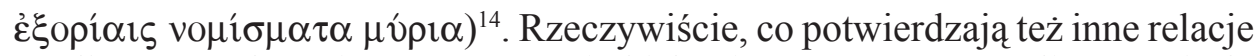
źródłowe, przebywający na wygnaniu biskupi często otrzymywali wsparcie finansowe ze strony swych stronników ${ }^{15}$. Dalszy przekaz Palladiusza dotyczący hojności Melanii nie jest już jednak jasny. Stwierdza on bowiem, iż taką samą sumę (czyli jak wysoką? 10 tys. solidów czy też 45 tys. solidów zliczając całą darowiznę?) Melania osobiście rozdała Kościołom na Zachodzie ( $\tau \alpha \hat{i} \varsigma$ $\kappa \alpha \tau \grave{\alpha}$

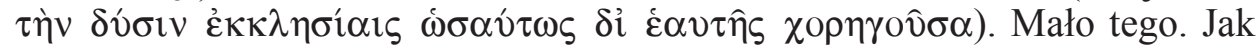
stwierdza Palladiusz:

„to wszystko, a do tego jeszcze sumę czterokrotnie wyższą ( $\tau \alpha \hat{v} \tau \alpha$ đó $v^{\prime} \tau \alpha$

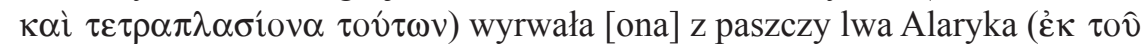
$\sigma \tau o ́ \mu \alpha \tau o \zeta ~ \lambda \varepsilon ́ o v \tau o \varsigma ~ ' A \lambda \alpha \rho i ́ \chi o v)$ dzięki swojej wierze i jakby z Bożego natchnienia" ${ }^{16}$.

Tym ostatnim stwierdzeniem Palladiusz sugeruje, iż wyżej wspomniane sumy uzyskano tylko ze sprzedaży italskich posiadłości Melanii.

W innym miejscu Historia Lausiaca czytamy, iż Melania Młodsza przekazała Doroteuszowi, jednemu z mnichów z Antinoe w Tebaidzie sumę 500 solidów $(\pi \varepsilon v \tau \alpha \kappa o ́ \sigma i \alpha v o \mu i ́ \sigma \mu \alpha \tau \alpha)$. Ten zaś stwierdzając, iż nie potrzebuje aż tak szczodrej darowizny rzekomo zostawił sobie zaledwie trzy sztuki złota ( $\tau \rho^{\prime} \alpha \lambda \alpha \beta \omega ̀ v \mu o ́ v \alpha$ ), resztę zaś sumy przekazał mnichowi Dioklesowi, który najprawdopodobniej pełnił $\mathrm{w}$ mniszym skupisku funkcje ekonoma ${ }^{17}$. Zasadność relacji obrazujących szczodrość Melanii Młodszej potwierdza również jej biograf, Geroncjusz ${ }^{18}$.

Wedle Palladiusza, Melania Młodsza w swej szczodrości wobec potrzebujących postępowała ścieżką wytyczoną przez jej babkę, Melanię Starszą, która na początku lat siedemdziesiątych IV w. zaczęła spieniężać swój majątek (w tym przypadku Palladiusz nie podaje jednak konkretnych sum), a uzyskane w ten sposób złoto i srebro wywozić na Wschód ${ }^{19}$, gdzie przebywała przez

${ }^{14}$ Por. Palladius, Historia Lausiaca 61, ed. C. Butler: The Lausiac History of Palladius, vol. 2: The Greek Text edited with introduction and notes, Cambridge 1904, 156. 10-13, thum. S. Kalinkowski: Palladiusz, Opowiadania dla Lausosa (Historia Lausiaca), ŹM 12, 220.

${ }^{15}$ Por. Milewski, Depozycje i zsyłki, s. 369-380.

${ }^{16}$ Por. Palladius, Historia Lausiaca 61, ed. Butler, s. 156. 15-16, ŹM 12, 220.

${ }^{17}$ Por. tamże 58, ed. Butler, s. 151. 23 - 152. 1, ŹM 12, 214.

${ }^{18}$ Por. Gerontius, Vita Melaniae iunioris 11-12, ed. D. Gorce, SCh 90, Paris 1962, 146-152; 21, SCh 90, 170-172. Zob. T. Špidlik, Melania la benefatrice (383-440), Milano 1986, 41-47 i 5761; L.L. Coon, Sacred Fictions: Holy Women and Hagiography in Late Antiquity, Philadelphia 1997, 115 (rozdział: „,Through the Eye of a Needle”. Wealth and Poverty in the Lives of Helena, Paula, and Melania the Younger); I. Milewski, Działalność dobroczynna przedstawicielek rodów arystokratycznych i domów panujacych we wschodnich prowincjach Cesarstwa w IV i V wieku, w: Partnerka, matka, opiekunka. Status kobiety w starożytności i średniowieczu, red. J. Jundziłł, Bydgoszcz 1999, 247-251.

${ }^{19}$ Por. Palladius, Historia Lausiaca 54, ed. Butler, s. 147. 5-18, ŹM 12, 208. Na temat Melanii Starszej por. F.X. Murphy, Melania the Elder: a biographical note, „Traditio” 5 (1947) 59-77; 
37 lat. Wedle zapewnień Palladiusza, Melania przez cały ten czas posiadała środki (dostarczane jej z Zachodu) na wsparcie tamtejszych biskupstw, klasztorów (przede wszystkim w Jerozolimie) oraz na prowadzenie działalności dobroczynnej ${ }^{20}$. Złoto zaś uzyskane ze sprzedaży posiadłości Melanii Starszej na Zachodzie dostarczali jej krewni oraz odbywający podróże na Wschód zarządcy jej majątków.

Szczodrość Melanii stała się udziałem nie tylko Palestyny, doświadczyli jej również egipscy mnisi. Palladiusz eksponuje w swym dziele jeden przykład (analogicznych zapewne było więcej). Melania podczas swej podróży po Egipcie miała przekazać nitryjskiemu mnichowi Pambo „srebrną szkatułę za-

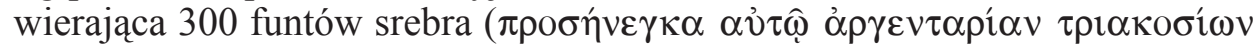

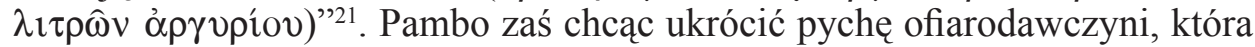
w samozadowoleniu stwierdzić miała, iż 300 funtów srebra to wielka suma, powiedział jej, że nie potrzebuje tego srebra i dlatego przekaże je potrzebującym, a mianowicie libijskim mnichom, gdyż - jak stwierdził - „tamtejsze

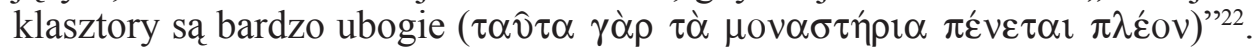
Ekonomowi ich wspólnoty, bliżej nie znanemu Orygenesowi, Pambo zabronił przekazać współbraciom czegokolwiek z otrzymanej sumy. Według niego bowiem Egipt był zasobną kraina, a tamtejsi mnisi pracą własnych rąk byli w stanie zaspokoić swe skromne potrzeby ${ }^{23}$.

Suma 300 funtów srebra, stanowiąca niemalże sto kilogramów tego kruszcu, była zawrotna, co akcentuje również sama Melania, oczekując podziękowania ze strony obdarowanego mnicha. Suma wydaje się jednak mało prawdopodobna i to bynajmniej nie ze względu na jej wysokość, co okrągłą liczbę, w tym przypadku wielokrotność cyfry trzy. Nie ma natomiast wątpliwości, że Melanię było stać na tak wysoką darowiznę. Analogiczne sumy transferowano wówczas na Wschód, a w tym konkretnym przypadku Melanii musiał towarzyszyć dość silny oddział zbrojny, prywatny lub też przydzielony przez lokalnego urzędnika, przy czym bez większego znaczenia pozostaje w tym przypadku fakt, czy Melania przekazałaby tylko dziesięć czy też nawet trzysta funtów srebra. Poza tym byłaby to zapewne tylko część kruszców, jakimi dysponowała w czasie swej wieloletniej podróży, tym bardziej, iż miała ona w planach rozdzielenie kolejnych darowizn. Nie przywiązując

P. Szczur, Melania Starsza, EK XII 488-489; K.W. Wilkinson, The Elder Melania's missing decade, „Journal of Late Antiquity” 5 (2012) 166-184.

${ }^{20}$ Por. Palladius, Historia Lausiaca 54, ed. Butler, s. 147.18, ŹM 12, 208. Zob. C. Krumeich, Hieronymus und die christliche feminae clarissimae, Bonn 1993, 80-91; E. Mitsiou, Frauen als Gründerinen von Doppelklöstern im Byzantinischen Reich, w: Female Founders in Byzantium and Beyond, ed. L. Theiss - M. Mullett - M. Grünbart - F. Fingarova - M. Savage, Wiener Jahrbuch für Kunstgeschichte 60-61, Wien - Köln - Weimar 2011-2012, 336-337.

${ }^{21}$ Por. Palladius, Historia Lausiaca 10, ed. Butler, s. 30. 8, ŹM 12, 96. W tłumaczeniu polskim czytamy o przekazaniu przez Melanię ,trzystu monet srebra” (tamże), co jest błędne.

${ }^{22}$ Tamże, ed. Butler, s. 30. 14-15, ŹM 12, 96.

${ }^{23}$ Por. tamże. 
wagi do wysokości rzekomej darowizny, chciałbym zwrócić uwagę na pewne dopowiedzenie wypowiedziane przez obdarowanego Pambo, który chcąc poskromić ewidentne samozadowolenie Melanii, płynące z faktu przekazania mnichowi tak wysokiej darowizny, stwierdza, iż „Ten, któremu to przyniosłaś [a więc Bóg], nie potrzebuje wagi. Kto bowiem potrafi zważyć góry, tym bardziej zna wagę srebra". Mało tego: nie należy się nazbyt afiszować z wysokością darowizny, skoro Bóg przyjmował już nawet tylko dwa obole ${ }^{24}$. Najważniejsza informacja z punktu widzenia naszych dociekań dotyczy tego, iż u schyłku antyku wysokie sumy odważano, a nie odliczano pojedynczych sztuk monet, co wypływało z faktu zróżnicowanej wagi pieniądza będącego w obiegu. Z reguły odstępowała ona od teoretycznych założeń ${ }^{25}$.

Analizując relacje Palladiusza, czy też innych współczesnych mu autorów chrześcijańskich, dotyczące hojności późnoantycznych ofiarodawców, nasuwa się pytanie o to, w jaki sposób postrzegać pojawiające się w źródłach stwierdzenia, iż szczodry darczyńca rozdał cały swój majątek ubogim? Czy rzeczywiście ubogim, czy też, że przekazał go Kościołowi na cele dobroczynne? Różnica jest tu zasadnicza. Z Historia Lausiaca wynika, iż kolejna z hojnych donatorek, Olimpias (wnuczka praefectus praetorio Ablabiusza i wdowa po Nebrydiuszu, zmarłym praefectus urbi Konstantynopola) ${ }^{26}$, rozdała cały swój majątek ubogim ${ }^{27}$, co jednak nie do końca jest prawdą. $\mathrm{Z}$ innej relacji Palladiusza (Dialogus de vita Joannis Chrysostomi), dowiadujemy się bowiem, iż poza wspieraniem konstantynopolitańskich biedaków, Olimpias sporą część swego majątku przekazała wielu Kościołom na Wschodzie, a nawet konkretnym biskupom, wśród których Palladiusz wymienia: Teofila Aleksandryjskiego, Epifaniusza, biskupa Salaminy, Amfilochiusza, biskupa Ikonium, Grzegorza, biskupa Nazjanzu, Piotra (zapewne brata Grzegorza z Nazjanzu) oraz bliżej nie znanego nam biskupa Optimusa. Jan, choć zaprzyjaźniony z Olimpias, uchodzi w relacji Palladiusza za ich przeciwieństwo. Nie dość, iż nie prosił jej o pieniądze, to jeszcze przestrzegał Olimpias przed chciwymi biskupami, którzy „niczym dzikie ptactwo rozdziobują jej majątek”"28.

${ }^{24}$ Por. tamże, ed. Butler, s. 30. 20-23, ŹM 12, 97.

${ }^{25} \mathrm{Na}$ temat wagi późnoantycznych nominałów bitych w złocie oraz srebrze por. J. Iluk, Ekonomiczne i polityczne aspekty cyrkulacji złota w późnym Cesarstwie Rzymskim, Gdańsk 1988, 5161; I. Milewski, Pieniqdz w greckiej literaturze patrystycznej IV wieku na przykładzie pism Kapadockich Ojców Kościoła i Jana Chryzostoma, Gdańsk 1999, 13-18.

${ }^{26}$ Por. G. Dagron, Naissance d'une capitale. Constantinople et ses institutions de 330 à 451, Paris 1974, 253-254; S. Rebenich, Hieronymus und sein Kreis. Prosopographische und Sozialgeschichtliche Untersuchungen, Stuttgart 1992, 121.

${ }^{27}$ Por. Palladius, Historia Lausiaca 56, ed. Butler, s. 150. 6-7, ŹM 12, 212. Zob. C. Broc, Le rôle des femmes dans l'Église de Constantinople d'après la correspondance de Jean Chrysostome, StPatr 27 (1993) 151-154; E.M. Synek, Heilige Frauen der frühen Christenheit. Zu den Frauenbildern in hagiographischen Texten des christlichen Ostens, Würzburg 1994, 175-181.

${ }^{28}$ Palladius, Dialogus de vita Joannis Chrysostomi 17, 197-205, SCh 341, 174, thum. własne. Por. G. Cloke, This Female Man of God. Women and Spiritual Power in the Patristic Age, AD 350- 
Oczywiście nie trzeba było być arystokrata, by przekazywać spore sumy na potrzeby ubogich. Są to już jednak proporcjonalnie mniejsze kwoty. Kolejni bohaterowie Palladiuszowych relacji to bliżej nie znani nam Paezjos i Izajasz, dwaj bracia z Aleksandrii, którzy po śmierci swego ojca, kupca z zawodu, odzie-

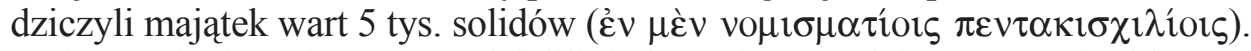
Po jego spieniężeniu sumę podzielili: jeden całość rozdał „na potrzeby klasztorów, kościołów i więzień", drugi zaś wzniósł za swoją część spadku klasztor, w którym przyjmował ,wędrowców, chorych, starych i biedaków”29.

W innym zaś miejscu Historii Lausiaca Palladiusz opisuje życie mnicha Filoromosa, który mieszkając na Pustyni Nitryjskiej (w grobowcu przy drodze prowadzącej do Aleksandrii) parał się przepisywaniem ksiag. Po czterdziestu latach uprawiania owej profesji miał zaoszczędzić sumę 250 solidów ${ }^{30}$. Suma ta wydaje się raczej realną do osiągnięcia po tylu latach parania się zarobkową kaligrafią. Jak potwierdza zapis w Edykcie o cenach maksymalnych ogłoszonym w 301 r. przez Dioklecjana zarobki kaligrafów, w porównaniu z dochodami uzyskiwanymi przez przedstawicieli innych zawodów, utrzymywały się wówczas na przyzwoitym poziomie ${ }^{31}$. Wspomniany Filoromos przekazał zaoszczędzone pieniądze na potrzeby ubogich z okolic Aleksandrii.

Kolejna grupa informacji, jakie odnajdujemy na temat pieniądza w Historia Lausiaca, dotyczy szeroko rozumianej działalnością Kościoła. Skuteczny w gromadzeniu środków na prowadzenie akcji dobroczynnej był działający w latach 70. IV w. jeden z prezbiterów Kościoła Aleksandryjskiego, Makary. Wielokrotnie odbierał on spore sumy pieniężne na cele dobroczynne, raz nawet 500 solidów ( $\pi \varepsilon v \tau \alpha \kappa o ́ \sigma 1 \alpha v$ vo 1 í $\mu \alpha \tau \alpha$ ), które przeznaczył na rozbudowę

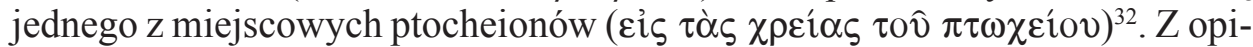
su Palladiusza wynika, iż darowizna ta została przez bohatera jego opowieści w pewnym stopniu ,wyłudzona”, co wynikało rzekomo z tego, iż darczyńca znany był w mieście ze swego skąpstwa, odmawiając wsparcia biedaków nawet jednym obolem, a więc przysłowiowym groszem. Stąd zastosowany przez Makarego fortel, mistyfikacja korzystnej transakcji finansowej. Darczyńca zobaczywszy, w jaki sposób wykorzystano pozyskane od niego środki miał stać się bardziej ofiarnym ${ }^{33}$. Relacjonowana przez Palladiusza opowieść, zapewne fikcyjna, miała podziałać dydaktycznie na tych, którzy nie chcą podzielić się dobrami, posiadanymi i tak w nadmiarze.

450, London - New York 1995, 179-180; W. Meyer, Constantinopolitan Women in Chrysostom's Circle, VigCh 53 (1999) 267nn.

${ }^{29}$ Por. Palladius, Historia Lausiaca 14, ed. Butler, s. 37.15 - 38. 7-8, ŹM 12, 103-104.

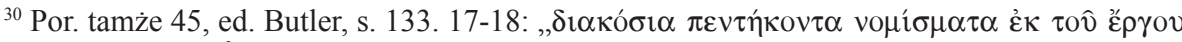
$\tau \hat{\omega} \vee \chi \varepsilon เ \rho \hat{\omega} \vee \alpha \hat{\tau} \tau 0 \hat{v} "$, ŹM 12, 193.

${ }^{31}$ Por. Edictum Diocletiani de pretiis rerum venalium VII 1, 39-40, Fontes Historiae Antiquae 9 [wyd. grecko-polskie, tłum. A. i P. Barańscy: Edykt Dioklecjana o cenach towarów wystawionych na sprzedaż, oprac. P. Janiszewski], Poznań 2007, 53.

${ }^{32}$ Por. Palladius, Historia Lausiaca 6, ed. Butler, s. 23. 16-25, ŹM 12, 88-89.

${ }^{33}$ Por. tamże, ed. Butler, s. 24. 8-20, ŹM 12, 89-90. 
W Historia Lausiaca pojawiają się także, choć szczątkowo, informacje na temat ówczesnych cen i płac. Palladiusz wspomina o wyzwoleniu 8 tys. niewolników przez Melanię Młodszą. Bliżej nieokreśloną „resztę” niewolników

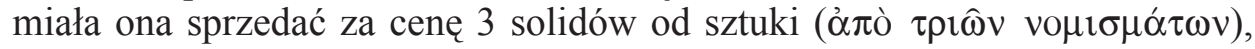
co oczywiście było sumą bardzo niską ${ }^{34}$. Czy informacja ta jest prawdziwa? Raczej wattpię i to co najmniej z dwóch powodów. Dlaczego Melania jednych niewolników miałaby wyzwolić a innych sprzedać? Zastrzeżenie budzi również wysokość sumy: w literaturze starochrześcijańskiej cyfra trzy to synonim małej wartości rzeczy, odzienie biedaka warte jest jeden, trzy bądź kilka oboli, a więc niewiele ${ }^{35}$. W łacińskiej literaturze patrystycznej tę rolę pełnią sumy wyrażone nummusami $^{36}$. Podobnie rzecz się ma z sumą trzech solidów - może więc oznaczać tyle co nic, ze względu jednak na wymierną wartość materialną sprzedanego niewolnika posłużono się w tym przypadku nominałem najwyższej wartości.

Z kolei w innym miejscu Historii Lausiaca Palladiusz podaje już inną

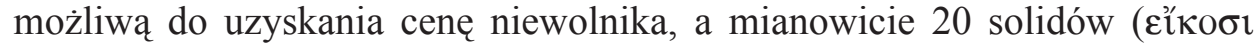
$v o \mu i ́ \sigma \mu \alpha \tau \alpha)$. Opisana przy tej okazji historia nieco dewaluuje jednak wartość poznawczą przekazanej informacji. Bohater sam sprzedał siebie w niewolę, a uzyskane w taki sposób pieniądze, jak stwierdza to Palladiusz, „opieczęto-

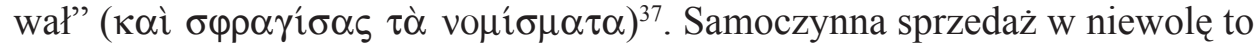
jeden $\mathrm{z}$ toposów literatury hagiograficznej ${ }^{38}$.

Wzmiankowana już powyżej suma 3 solidów, pojawia się również w innej opisywanej przez Palladiusza historii i dotyczy pewnej nieznanej z imienia mniszki, która w młodości, będąc niewolnica, miała być wypożyczana przez swego właściciela do domu publicznego za sumę trzech solidów dziennie

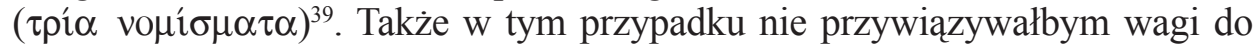
wysokości podanej sumy. Razu pewnego miano jej nawet zaoferować pięć soli-

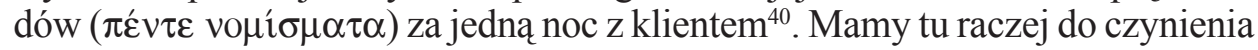
z historią fikcyjna, toposem przedstawiającym chrześcijankę, późniejsza mniszkę, która umieszczoną w domu publicznym pozostała wierna Chrystusowi.

W Historia Lausiaca odnajdujemy jeszcze szereg drobnych już jednak relacji, nawiązujących do pieniądza jako chociażby symbolu życia świeckiego ${ }^{41}$, synonimu marności; stwierdzenia typu: mnisze odzienie nie jest warte nawet

\footnotetext{
${ }^{34}$ Por. tamże 61, ed. Butler, s. 156. 16-19, ŹM 12, 220.

${ }^{35}$ Por. Milewski, Pieniqdz w greckiej literaturze patrystycznej IV wieku, s. 23.

${ }^{36}$ Por. J. Jundziłł, Pieniadz w tacińskiej literaturze chrześcijańskiej późnego Cesarstwa Rzymskiego, Warszawa 1984, 29 i 50-52.

${ }^{37}$ Por. Palladius, Historia Lausiaca 37, ed. Butler, s. 109. 11-13, ŹM 12, 171.

${ }^{38}$ Por. H. Bellen, Mâllon chrêsai (1 Cor. 7, 21). Verzicht auf Freilassung als asketische Leistung, JACh 6 (1963) 179.

${ }^{39}$ Por. Palladius, Historia Lausiaca 65, Butler, s. 161. 12, ŹM 12, 225.

${ }^{40}$ Por. tamże, ed. Butler, s. 161. 24-25, ŹM 12, 226.

${ }^{41}$ Por. tamże 35, ed. Butler, s. 105. 15-18, ŹM 12, 167: „Czterdzieści osiem lat mieszkam w tej celi i nie widziałem kobiecej twarzy ani pieniędzy".
} 
jednego obola ${ }^{42}$, albo nie zrobię tego czy owego za nawet 100 sztuk złota

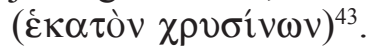

W zestawionym materiale źródłowym w przeważającej mierze pojawia się pieniądz złoty, solidy, co warunkowane jest charakterem przytaczanych relacji, w których wspomina się o wysokich sumach przekazywanych przez przedstawicieli arystokracji głównie na cele dobroczynne bądź też szeroko rozumianą działalność kościelną. Jak postrzegać informacje o sumach pieniężnych przekazywanych przez hojnych darczyńców na cele dobroczynne? Nie przywiązywałbym większej wagi do ich wysokości. Stwierdzenie, iż ten czy inny darczyńca przekazał na przykład 10 tys. solidów lub talentów złota bądź srebra, nie należy postrzegać dosłownie. Tego typu stwierdzenie znaczy tyle co „bardzo dużo”, a w rzeczywistości zapewne jeszcze więcej niż podana suma. Analogicznie rzecz się ma również z cyfrą trzy, ze stwierdzeniami, że ktoś zgubił 3 solidy, ktoś otrzymał bądź zapłacił za coś 3 solidy. Zwróćmy uwagę, iż to właśnie cyfry jeden (oraz liczby: 10, 100, 1000, 10000 100000) i trzy (oraz liczby: 30, 300 lub też 3000) najczęściej pojawiają się w greckiej literaturze patrystycznej. Stąd też chyba zasadne domniemanie, iż nie należy postrzegać ich dosłownie. Co oczywiste, wspomniane powyżej cyfry i liczby pojawiają się we wszystkich antycznych tekstach literackich.

Aby jednak nie przekreślać wartości poznawczej zestawionych powyżej relacji warto zwrócić uwagę nie tyle na wysokość przekazywanych sum, lecz na samo zjawisko oraz jego intensyfikację, na informacje, kto i w jakim celu przekazywał owe darowizny. Hojność obydwu Melanii, potwierdzana również innymi relacjami źródłowymi ${ }^{44}$, nie była oczywiście wyjątkiem. Analogicznie wysokie sumy na rzecz Kościoła oraz działalność dobroczynną przekazywały wówczas inne arystokratki (najbardziej znana spośród nich to Olimpias $^{45}$, wspomniana dość ogólnikowo jednak przez Palladiusza w Historia

${ }^{42}$ Por. tamże 68, ed. Butler, s. 164. 15, ŹM 12, 229: „Ubranie jego nie było warte jednego grosza”.

${ }^{43}$ Por. tamże 37, ed. Butler, s. 113. 13, ŹM 12, 174.

${ }^{44}$ Paulinus Nolanus, Epistula 29, 5-6, ed. G. Hartel, CSEL 29, Wien 1894, 251-252 (Melania Starsza wspiera mnichów nitryjskich). Hieronim jednak wychwalając działalność dobroczynną arystokratek, nie wspomina o środkach wyłożonych przez Melanię Starszą. S. Wittern (Frauen, Hieligkeit und Macht. Lateinische Frauenviten aus dem 4. bis 7. Jahrhundert, Stuttgart - Weimar 1994, 23) twierdzi, iż wypływało to z faktu, iż Melania Starsza współpracowała z Rufinem z Akwilei, zwalczanym przez Hieronima orygenista. Hieronim wspomina o Melanii w negatywnej relacji nawiązując jedynie do jej rzekomo orygenistycznych sympatii.

${ }^{45}$ Olimpias i jej darowizny: Vita S. Olympiadis V 21-33, ed. A.-M. Malingrey, w: Jean Chrysostome, Lettres a Olympias. Vie anonyme d'Olympias, SCh 13bis, Paris 1968, 418; VII 3-4, SCh 13bis, 420. Olimpias miała przekazać na rzecz stołecznego biskupstwa w czasach Jana Chryzostoma 10 tys. funtów złota, 20 tys. funtów srebra oraz wiele nieruchomości posiadanych przez nią na terenie Tracji, Galacji, Kapadocji, Bitynii, a nawet w samym Konstantynopolu i na jego przedmieściach. W tej kwestii por. także Dagron, Naissance d'une capitale, s. 501-506; Cloke, This Female Man of God, s. 179-180. 
Lausiaca $^{46}$ ) oraz, co nie dziwi, kobiety z domu cesarskiego ${ }^{47}$. Informacje dotyczące darowizn podawane przez Palladiusza (analogiczne dane znamy również z innych źródeł) potwierdzają istotne zjawisko, a mianowicie $\mathrm{z}$ jednej strony drenaż rynku pieniężnego ze złota i srebra na Zachodzie (tam głównie były umiejscowione spieniężane majątki rzymskiej arystokracji senatorskiej), transfer pozyskanych kruszców na Wschód, a następnie lokowanie wielkich sum w większości bezproduktywne (z ekonomicznego punktu widzenia) albo też mało produktywne (choć czasami istotne ze względu na interes społeczny, pomijając już kwestie religijne) inwestycje w postaci wsparcia ubogich, budowę czy też rozbudowę kościelnej infrastruktury (bazyliki, kościoły, martyriony, centra pielgrzymkowe) ${ }^{48}$. Drenaż rynku pieniężnego na Zachodzie musiał być wówczas znaczny i postrzegany jako niekorzystny dla tamtejszego rynku pieniężnego, skoro cesarz Honoriusz, chcąc zatrzymać (a przynajmniej ograniczyć) to zjawisko, zabronił sprzedaży ziemi w zachodnich prowincjach cesarstwa, jak też wywozu kruszców na Wschód ${ }^{49}$. Pamiętajmy, że Imperium Rzymskie jest już rządzone przez dwóch cesarzy zmuszonych stawiać czoła zróżnicowanym zagrożeniom, co miało też konkretny wpływ na prowadzoną przez nich politykę, także politykę gospodarczą państwa. Poza tym w interesie dworu raweńskiego, któremu coraz bardziej doskwierał brak pieniądza na pokrycie kosztów funkcjonowania państwa, absolutnie nie zależało na ekonomicznym wsparciu dworu konstantynopolitańskiego, bo tym skutkował transfer olbrzymich ilości kruszców szlachetnych na Wschód ${ }^{50}$.

Zestawione powyżej relacje, choć nieco ułomne w swym przekazie wzbogacają naszą wiedzę na temat późnorzymskiej gospodarki, jak również mających wówczas miejsce przemian społeczno-religijnych. Oceniając ich walory poznawcze pamiętać należy, iż Palladiusz przekazane nam informacje zebrał spędzając wiele lat w Palestynie, w Egipcie czy też w Konstantynopolu poznając tam najhojniejsze ofiarodawczynie, Melanię Starszą, Melanię Młodszą oraz

${ }^{46}$ Por. Palladius, Historia Lausiaca 56, ed. Butler, s. 150. 6-7, ŹM 12, 212. Palladiusz stwierdza jedynie, iż Olimpias „Cały swój majątek rozdała ubogim” (tamże).

47 Por. D.J. Constantelos, Byzantine Philantropy and Social Welfare, New Brunswick - New Yersey 1968, 112, 139, 262-264 i 268; K.G. Holum, Theodosian Empresses. Women and Imperial Dominion in Late Antiquity, Berkeley 1982, 189 i 219; J.U. Krause, Witwen und Weisen im frühen Christentum, Stuttgart 1995, 95-97; Milewski, Działalność dobroczynna przedstawicielek rodów arystokratycznych, s. 245-259.

${ }^{48}$ Por. W. Jongman, Gibbon was Right. The Decline and Fall of the Roman Economy, w: Crises and the Roman Empire. Proceedings of the seventh Workshop of the International Network. Impact of Empire (Nijmegen, June 20-24, 2006), ed. O. Helister - G. de Kleijn - D. Sloothes, Leiden - Boston $2007,183 \mathrm{nn}$.

${ }^{49}$ Por. Gerontius, Vita Melaniae iunioris 11-12, ed. D. Gorce, SCh 90, Paris 1962, 146-152; 21, SCh 90, 170-172. Zob. Špidlik, Melania la benefatrice, s. 57-61.

${ }^{50}$ Por. M. Avi-Yonah, The Economics of Byzantine Palestine, „Israel Exploration Journal” 8 (1958) 39nn; Iluk, Ekonomiczne i polityczne aspekty cyrkulacji złota, s. 96; Krause, Witwen und Weisen im frühen Christentum, s. 107. 
Olimpias. Teksty hagiograficzne, w tym Historia Lausiaca, pomimo szeregu ułomności poznawczych pozostają cennym źródłem poznania historycznego. Dlatego też, w celu pozyskania niewykorzystanych dotychczas danych w badaniach nad gospodarką późnoantyczną, warto przeprowadzić gruntowną analizę całej ówczesnej literatury chrześcijańskiej, pamiętając, iż mimo częstego braku precyzji w przekazie, źródła te pozwalają na pełniejszą rekonstrukcję dziejów późnego cesarstwa rzymskiego, szczególnie zaś życia codziennego w prowincjach.

\section{MONEY IN HISTORIA LAUSIACA BY PALLADIUS OF HELENOPOLIS}

\section{(Summary)}

The paper analyses the reports regarding money, which appear in the Historia Lausiaca by Palladius, bishop of bithynian Helenopolis and galatian Aspona. In the work of Palladius, money appears in several contexts: as a donation to a church and sums donated to charity. Amongst the most generous donors, there are: Melania the Elder, Melania the Younger and Olympias from Constantinople. In Historia Lausiaca, there can also be found some information about the prices and wages of the time. Another matter is the credibility of the reports when it comes to the amounts of money. Unfortunately, it is extremely difficult to ultimately verify their legitimacy. Other reports which give information on the prices and wages are not really helpful either.

Key words: Antiquity, Ancient Christianity, Economy of the Later Roman Empire, early Byzantium, Palladius of Helenopolis.

Słowa kluczowe: starożytność, antyczne chrześcijaństwo, ekonomia późnego cesarstwa rzymskiego, wczesne Bizancjum, Palladiusz z Helenopolis.

\section{BIBLIOGRAFIA}

\section{Źródła}

Edictum Diocletiani de pretiis rerum venalium, Fontes Historiae Antiquae 9 [wyd. greckopolskie, tłum. A. i P. Barańscy: Edykt Dioklecjana o cenach towarów wystawionych na sprzedaż, oprac. P. Janiszewski], Poznań 2007.

Gerontius, Vita Melaniae iunioris, éd. D. Gorce, SCh 90, Paris 1962.

Joannes Chrysostomus, Epistulae, PG 52, 529-791.

Palladius, Dialogus de vita Joannis Chrysostomi, éd A. M. Malingrey - P. Leclercq, SCh 341, Paris 1988.

Palladius, Historia Lausiaca, ed. C. Butler: The Lausiac History of Palladius, vol. 2: The Greek Text edited with introduction and notes, Cambridge 1904; thum. S. Kalinkowski: Palladiusz, Opowiadania dla Lausosa (Historia Lausiaca), ŹM 12, Kraków - Tyniec 1996.

Paulinus Nolanus, Epistulae, ed. G. Hartel, CSEL 29, Wien 1894. 
Vita S. Olympiadis, ed. A.-M. Malingrey, w: Jean Chrysostome, Lettres a Olympias. Vie anonyme d'Olympias, SCh 13bis, Paris 1968, 406-449.

Opracowania

Avi-Yonah M., The Economics of Byzantine Palestine, „Israel Exploration Journal” 8 (1958) 39-51.

Bellen H., Mâllon chrêsai (1 Cor. 7, 21). Verzicht auf Freilassung als asketische Leistung, JACh 6 (1963) 177-180.

BRoc C., Le rôle des femmes dans l'Église de Constantinople d'après la correspondance de Jean Chrysostome, StPatr 27 (1993) 150-154.

Cloke G., This Female Man of God. Women and Spiritual Power in the Patristic Age, AD 350-450, London - New York 1995.

Consolino F.E., Sante o patrone? Le aristocratiche tardoantiche e il potere della carità, „Studi Storici” 30 (1989) 969-991.

Constantelos D.J., Byzantine Philantropy and Social Welfare, New Brunswick - New Yersey 1968.

Coon L.L., Sacred Fictions: Holy Women and Hagiography in Late Antiquity, Philadelphia 1997, 95-119.

Dagron G., Naissance d'une capitale. Constantinople et ses institutions de 330 à 451, Paris 1974.

Holum K.G., Theodosian Empresses. Women and Imperial Dominion in Late Antiquity, Berkeley 1982.

HüBner A., Einführung, w: Palladius, Historia Lausiaca. Geschichte aus dem frühen Mönchtum, Übersetzt und kommentiert von A. Hübner, FCh 67, Freiburg - Basel Wien 2016, 7-77.

Hunt E.D., Palladius of Helenopolis. A Party and its Supporters in the Church of the Late Fourth Century, JTS 24 (1973) 456-480.

ILuK J., Ekonomiczne i polityczne aspekty cyrkulacji złota w późnym Cesarstwie Rzymskim, Gdańsk 1988.

Jongman W., Gibbon was Right. The Decline and Fall of the Roman Economy, w: Crises and the Roman Empire. Proceedings of the seventh Workshop of the International Network. Impact of Empire (Nijmegen, June 20-24, 2006), ed. O. Helister - G. de Kleijn - D. Sloothes, Leiden - Boston 2007, 183-200.

Jundzıı J., Pieniadz w tacińskiej literaturze chrześcijańskiej późnego Cesarstwa Rzymskiego, Warszawa 1984.

Katos D.S., Palladius of Helenopolis. The Origenist Advocate, Oxford 2011.

Krause J.U., Witwen und Weisen im frühen Christentum, Stuttgart 1995.

KRUMEICH C., Hieronymus und die christliche feminae clarissimae, Bonn 1993.

Lexikon der Antiken christlichen Literatur, hrsg. von S. Doepp - W. Geerlings, Freiburg - Basel - Wien 1998.

Meyer W., Constantinopolitan Women in Chrysostom's Circle, VigCh 53 (1999) 265-288.

Milewski I., Depozycje $i$ zsylki biskupów w cesarstwie wschodniorzymskim (lata 325451), Gdańsk 2008.

Milewski I., Działalność dobroczynna przedstawicielek rodów arystokratycznych $i$ domów panujacych we wschodnich prowincjach Cesarstwa w IV i V wieku, w: Partnerka, matka, opiekunka. Status kobiety w starożytności i średniowieczu, red. J. Jundziłł, Bydgoszcz 1999, 245-259. 
Milewski I., Jan Chryzostom i jego stronnicy w starciu z patriarchq aleksandryjskim Teofilem, w: Czasy Jana Chryzostoma i jego pasterska pedagogia, red. N. Widok, Opolska Biblioteka Teologiczna 105, Opole 2008, 87-116.

Milewski I., Pieniqdz w greckiej literaturze patrystycznej IV wieku na przykładzie pism Kapadockich Ojców Kościoła i Jana Chryzostoma, Gdańsk 1999.

Mitsiou E., Frauen als Gründerinen von Doppelklöstern im Byzantinischen Reich, w: Female Founders in Byzantium and Beyond, ed. L. Theiss - M. Mullett - M. Grünbart F. Fingarova - M. Savage, Wiener Jahrbuch für Kunstgeschichte 60-61, Wien - Köln - Weimar 2011-2012, 333-343.

Murphy F.X., Melania the Elder: a biographical note, „Traditio” 5 (1947) 59-77.

Prosopography of the Later Roman Empire, II: A.D. 395-527, ed. J.R. Martindale, Cambridge 1980.

Rebenich S., Hieronymus und sein Kreis. Prosopographische und Sozialgeschichtliche Untersuchungen, Stuttgart 1992.

Salzmann M.R., The Making of a Christian Aristocracy. Social and Religious Change in the Western Roman Empire, Cambridge - London 2002.

Schulze Ch., Die Wundererzählungen in Palladius' Historia Lausiaca. Eine medizinhistorische Betrachtung, ZACh 17 (2013) 87-101.

Š́iduik T., Melania la benefatrice (383-440), Milano 1986.

Starowieyski M., Wstęp, w: Palladiusz, Opowiadania dla Lausosa (Historia Lausiaca), ŹM 12, Kraków 1996, 11-54.

Synek E.M., Heilige Frauen der frühen Christenheit. Zu den Frauenbildern in hagiographischen Texten des christlichen Ostens, Würzburg 1994.

Szczur P., Melania Młodsza, EK XII 488.

Szczur P., Melania Starsza, EK XII 488-489.

Tougher S., The Eunuch in Byzantine History and Society, London - New York 2008.

WiLkinson K.W., The Elder Melania's missing decade, „Journal of Late Antiquity” 5 (2012) 166-184.

WiPszycKa E., „Historia Lausiaca” Palladiusza, w: Chrześcijaństwo u schyłku starożytności. Studia źródłoznawcze, red. T. Derda - E. Wipszycka, I, Warszawa 1997, 229-280.

WitTERn S., Frauen, Hieligkeit und Macht. Lateinische Frauenviten aus dem 4. bis 7. Jahrhundert, Stuttgart - Weimar 1994.

WóscıK M., Fundacje dobroczynne w rzymskim prawie poklasycznym, Lublin 2003. 
